\title{
Revista Colombiana de

\section{Effect of dancing and nutrition education on hemodynamic and autonomic status in adults with metabolic syndrome: a randomized controlled clinical trial}

\author{
Jaime Gallo-Villegas ${ }^{\mathrm{a}, \mathrm{b}, *}$, Alexandra Pérez-Idárraga ${ }^{\mathrm{c}}$, Katerine Valencia-Gómez ${ }^{\mathrm{d}}$, \\ Deiber Pinzón-Castro ${ }^{d}$, Mónica Arenas-Sosa ${ }^{e}$, Mario Quintero-Velásquez ${ }^{f}$, \\ Dagnovar Aristizábal-Ocampo ${ }^{\mathrm{b}}$
}

\author{
a School of Medicine, University of Antioquia. GRINMADE Research Group, University of Antioquia, Medellín, Colombia \\ b SICOR Clinical and Research Center, Medellín, Colombia \\ c School of Medicine, University of Antioquia, Medellín, Colombia \\ 'COMFAMA, Medellín, Colombia \\ e Program "For Your Health, Move", Indeportes-Antioquia, Medellín, Colombia \\ f Sports Medicine, Indeportes-Antioquia, Medellín, Colombia
}

Received 10 December 2015; accepted 7 January 2016

Available online 8 April 2016

\section{KEYWORDS \\ Cardiovascular system; Hemodynamics; Autonomic nervous system; Exercise; Nutrition}

\begin{abstract}
Background: Although the benefits of exercise and changes in lifestyle on components of the metabolic syndrome (MS) have been described, little is known about the effect of dancing and nutritional changes on the cardiovascular system.

Objective: Evaluate the effect of an intervention based on dancing and nutrition education on hemodynamic and autonomic status in adults with MS.

Methods: A randomized controlled clinical trial was conducted involving 59 adults with MS. The intervention lasted 12 weeks and consisted of an aerobic exercise program (dancing) at an intensity of $60-75 \%$ of heart rate reserve, 60 minutes 3 times a week, and muscle strength training at an intensity of $50 \%$ of a maximum repetition, 30 minutes twice a week. The nutrition education program consisted of 2-hour workshops each week. Assessment of impedance cardiography and function of nervous system with analysis of heart rate variability (HRV) were made before and after the intervention.

Results: In the intervention group, a decrease in mean arterial pressure of $-7.8 \mathrm{mmHg}(95 \%$ $\mathrm{Cl},-12.84$ to $-2.75 ; P=0.004$ ) was found as well as in the systemic vascular resistance (SVR) index of -864.29 dyn.s. $\mathrm{m}^{2} / \mathrm{cm}^{5}(95 \% \mathrm{Cl},-1506.31$ to $-222.26 ; P=0.010)$. Increase was observed in
\end{abstract}

\footnotetext{
* Corresponding author.

E-mail address: jaime.gallo@udea.edu.co (J. Gallo-Villegas).
} 
the cardiac output index of $0.48 \mathrm{~L} / \mathrm{min} / \mathrm{m}^{2}(95 \% \mathrm{Cl}, 0.14$ to $0.83 ; P=0.007)$. In the spectral analysis of HRV a reduction in LF/HF ratio of $-0.52(95 \% \mathrm{Cl},-1.02$ to $-0.02 ; P=0.040)$ was also found.

Conclusions: An intervention with dancing and nutrition education lowers arterial blood pressure and SVR and has favorable effects on the sympathovagal balance in patients with MS.

(c) 2016 Sociedad Colombiana de Cardiología y Cirugía Cardiovascular. Published by Elsevier España, S.L.U. This is an open access article under the CC BY-NC-ND license (http:// creativecommons.org/licenses/by-nc-nd/4.0/).

\section{PALABRAS CLAVE \\ Sistema \\ cardiovascular; \\ Hemodinamia; \\ Sistema nervioso \\ autónomo; \\ Ejercicio; \\ Nutrición}

\section{Efecto del baile y la educación nutricional sobre el estado hemodinámico y autonómico en adultos con síndrome metabólico: un ensayo clínico controlado aleatorio}

\begin{abstract}
Resumen
Antecedentes: Aunque se describieron los beneficios del ejercicio y cambios en el estilo de vida sobre los componentes del síndrome metabólico (SM), poco se sabe del efecto del baile y la nutrición en el sistema cardiovascular.

Objetivo: Evaluar el efecto de una intervención de baile y educación nutricional sobre el estado hemodinámico y autonómico en adultos con SM.

Materiales y métodos: Ensayo clínico controlado que incluyó 59 adultos con SM. La intervención duró 12 semanas y consistió en un programa de baile a una intensidad del 60 a $75 \%$ de la frecuencia cardiaca de reserva, 60 minutos, 3 veces a la semana, y entrenamiento de la fuerza a una intensidad del 50\%, 30 minutos dos veces a la semana. El programa nutricional consistió en talleres de 2 horas cada semana. La cardiografía de impedancia y el análisis de la variabilidad de la frecuencia cardiaca (VFC) fueron realizados antes y después de la intervención.

Resultados: El grupo de intervención disminuyó la presión arterial media en $-7,8 \mathrm{mmHg}$ (IC $95 \%,-12,84$ a $-2,75 ; p=0,004)$ y el índice de resistencia vascular sistémica (RVS) en $-864,29$ dyn.s. $\mathrm{m}^{2} / \mathrm{cm}^{5}$ (IC 95\%, -1506,31 a -222,26; $\left.\mathrm{p}=0,010\right)$; y aumentó, el índice de gasto cardiaco en $0,48 \mathrm{~L} / \mathrm{min} / \mathrm{m}^{2}$ (IC 95\%, 0,14 a 0,83; $\left.\mathrm{p}=0,007\right)$. En la VFC se reportó una reducción en la relación LF/HF de -0,52 (IC 95\%, -1,02 a -0,02; $p=0,040$ ).

Conclusiones: Una intervención de baile y educación nutricional disminuye la presión arterial y la RVS y tiene efectos favorables en el balance simpático-vagal en pacientes con SM.

(C) 2016 Sociedad Colombiana de Cardiología y Cirugía Cardiovascular. Publicado por Elsevier España, S.L.U. Este es un artículo Open Access bajo la licencia CC BY-NC-ND (http:// creativecommons.org/licenses/by-nc-nd/4.0/).
\end{abstract}

\section{Introduction}

Metabolic syndrome (MS) is a clinical condition with a high prevalence, ${ }^{1}$ mainly due to changes in the Western lifestyle, which predispose to an increased risk of coronary events. ${ }^{2}$ Early recognition and proper diagnosis of people with MS are clinically relevant because patients require aggressive strategies of pharmacological and non-pharmacological treatment. ${ }^{2}$ MS is associated with insulin resistance and abdominal obesity and includes a series of alterations in vascular and metabolic function. ${ }^{3}$

Insulin resistance observed in patients with MS leads to an increase in insulin secretion (hyperinsulinemia), which has deleterious effects on the cardiovascular system. ${ }^{4}$ Although insulin has a vasodilatory effect, ${ }^{5}$ when endothelial dysfunction is present, activation of the sympathetic autonomic nervous system (ANS) is predominant, as are its corresponding hemodynamic consequences, such as increased heart rate, myocardial contractility, stroke volume, cardiac output, systemic vascular resistance (SVR), and arterial blood pressure. ${ }^{6,7}$ An increase in sympathetic tone increases the risk of cardiovascular death, and at the same time is related to metabolic disorders such as obesity, insulin resistance, type 2 DM, and MS. ${ }^{6}$

Exercise training and a healthy diet have favorable effects on different cardiovascular risk factors such as arterial hypertension, dyslipidemia, DM, and obesity. ${ }^{8}$ Exercise and good eating habits change body composition, ${ }^{8}$ increase insulin sensitivity ${ }^{8}$ and baroreflex sensitivity, ${ }^{9}$ improve endothelial function, ${ }^{10}$ hemorheology, hemostasis and sympathovagal balance, ${ }^{10,11}$ reduce inflammation, ${ }^{10}$ and slow the progression of atherosclerotic lesions. ${ }^{8}$ However, despite the current evidence on the beneficial effects of exercise and diet, adherence to intervention programs is low. ${ }^{12}$

Dancing is a type of exercise that can be adapted culturally in each region in order to increase adherence which has been associated with a lower risk of MS in middle-aged and older people. ${ }^{13}$ Dancing has also been used as treatment and rehabilitation of patients with different risk factors and 
chronic diseases, ${ }^{14}$ because it improves aerobic power, lower body muscle endurance, strength and flexibility, balance, agility, and gait in the elderly. ${ }^{15}$

Although there have been reports of the combined and individual benefits of exercise and nutrition education programs on cardiovascular risk factors, ${ }^{8,16,17}$ to our knowledge no studies have been conducted to measure the effect of dancing and diet on hemodynamic and autonomic variables simultaneously in high-risk patients.

The aim of this study was to evaluate the effect of an intervention based on dancing and nutrition education on hemodynamic and autonomic status in adults with MS. It was hypothesized that this intervention decreases arterial blood pressure, SVR and sympathetic tone.

\section{Methods}

A randomized controlled clinical trial was conducted on adults with MS in the municipality of Valparaíso, Antioquia (Colombia). The assignment of subjects to the intervention or control group was randomized through a sequence of random numbers generated by computer at a $1: 1$ ratio. Those who measured the outcomes were blinded to the group assignments.

\section{Subjects}

Men and women diagnosed with MS who met three or more criteria were included, according to the latest Intersociety Consensus. ${ }^{2}$ They were aged $30-60$ years and lived in the urban area of the municipality of Valparaíso or in a rural area near the county seat. People excluded from the study were those with a body mass index $>40 \mathrm{~kg} / \mathrm{m}^{2}$, those who had a history of a previous cardiovascular event, chronic diseases such as stage 4 or 5 kidney failure, chronic obstructive pulmonary disease, cancer, acquired immunodeficiency syndrome, type $1 \mathrm{DM}$, or uncontrolled blood pressure $>160 / 100 \mathrm{~mm} \mathrm{Hg}$, physical or cognitive limitations, pregnant women, and those subjects who had planned undergoing bariatric surgery.

\section{Intervention}

Before starting the intervention, the control group and the intervention group received general recommendations about exercise and healthy eating, and continued with the conventional treatment of the disease in the local hospital.

The intervention group received an exercise and nutrition education program for 12 weeks. An introduction was performed in the week prior to the start of the intervention; motivation and familiarization sessions were conducted with the exercise routine and the education program. Exercise program planning was carried out by a medical specialist in medicine applied to physical activity and sport, a dance teacher with extensive experience in the area, and a physical educator. A female teacher previously trained in the protocol conducted the sessions.

The aerobic training component consisted of dancing classes of continuous type, at intensity between $60-75 \%$ of heart rate reserve, 3 days a week with a duration of
60 minutes per session, including 5 minutes of warm-up and 5 minutes of cool-down. In addition, muscle strengthening was performed, including stimulation of five large muscle groups twice a week on alternate days for 30 minutes. The exercises were performed as circuits, which permitted strength resistance exercises. The initial load was approximately $50 \%$ of one maximum repetition (3 sets of 20 repetitions), which increased progressively every 3 weeks, depending on the evolution of each individual. The total exercise volume was $\mathbf{2 4 0}$ minutes per week. Aerobic exercise intensity was controlled by a Polar Team ${ }^{2}{ }^{\circledR}$ (Polar, Finland) system and the Borg scale of perceived exertion.

The nutritional education component was based on the transtheoretical model ${ }^{18}$ and included a 2 -hour educational session each week. The strategy of Information, Education, and Communication was applied ${ }^{19}$ including lectures, workshops, one goal educational primer, one erasable poster of nutritional labels, and one banner to highlight the goal of each week. In the first two sessions, a psychologist addressed issues related to habits, satiety, and appetite. Subsequently, a previously trained dietitian-nutritionist developed 10 workshops on nutrition education, with a focus on knowledge, attitudes, and practices, stressing the protective and risk factors for cardiovascular disease derived from food. The methods used in this study have been previously reported. 20

\section{Evaluation of oxygen consumption and muscle strength}

Maximal oxygen consumption was assessed in the physiology laboratory of Indeportes-Antioquia, through the Bruce protocol $^{21}$ on a Quinton ${ }^{\circledR} 1845$ (Quinton Cardiology Inc., EEUU) treadmill. Prior to the test, the procedure to be performed was explained to each subject; heart rate and blood pressure were determined according to the recommendations of the European Society of Hypertension, ${ }^{22}$ after a rest period of 5 minutes in the sitting position. The test ended when the patient requested termination due to fatigue, heart rate stabilization despite the increase in stress intensity, or in the presence of symptoms such as dizziness, chest pain, or dyspnea. Based on the time spent, maximal oxygen consumption $\left(\mathrm{VO}_{2}\right.$ max) was estimated with a regression formula. ${ }^{21}$

Strength was evaluated from a test of 10 to 12 maximal repetitions of the flexor and extensor muscle groups of the elbows, as well as flexors and extensors of the legs. From a regression formula, the maximum weight that the individual could lift in each exercise was calculated. ${ }^{23}$ Additionally, the number of repetitions of abdominal crunches and situps that each subject performed in 1 minute was recorded using a standardized test. ${ }^{23}$

\section{Assessment of body composition}

Height was measured with a Seca ${ }^{\circledR}$ (Seca, Germany) measuring rod; body weight with Health Meter ${ }^{\circledR}$ (Sunbeam Products Inc., EEUU) scales that had capacity of $181.4 \mathrm{~kg}$ and accuracy of $0.1 \mathrm{~kg}$, and waist circumference with a glass-fiber anthropometric tape. In addition, four skinfolds (biceps, triceps, subscapular, and suprailiac) were measured with 
a Slim Guide ${ }^{\circledR}$ (Creative Engineering Inc., EEUU) caliper according to the technique described by Lohman. ${ }^{24}$ Body fat percentage was obtained from the formula of Durnin and Womersaley. ${ }^{25}$

\section{Hemodynamic and autonomic evaluation}

Each individual who participated in the study was instructed to avoid the consumption of tobacco, liquor, or hallucinogenic substances and to avoid physical activity for 24 hours before evaluation. Hemodynamic and autonomic function were recorded between 8 and $10 \mathrm{a} . \mathrm{m}$. in an environment at $20^{\circ} \mathrm{C}$ without visual or auditory distractors after a rest period of 15 minutes, in the sitting position for 5 minutes, and then in the standing position for another 5 minutes. The assessment was performed with MP150 (BIOPAC Systems, Inc., Goleta, CA), according to current recommendations for performing impedance cardiography. ${ }^{26}$ For measurement, analysis, and processing of data, AcqKnowledge software was used. Arterial blood pressure was measured at the end of each stage with a calibrated sphygmomanometer as recommended by the European Society of Hypertension. ${ }^{22}$ Taking into account arterial blood pressure, electrocardiographic recording, and impedance cardiography data, estimates were obtained for the RR interval, heart rate, stroke volume, cardiac output, mean arterial pressure, SVR, pre-ejection period, ejection time, speed index, acceleration index, and left ventricular work as described. ${ }^{26}$

Autonomic function was assessed from the RR interval record obtained from the electrocardiograph included in MP150 (BIOPAC Systems, Inc., Goleta, CA) under control of breathing to 15 cycles per minute. The electrocardiograph data were visually reviewed for anomalies and movement artifacts. These were analyzed off-line using Kubios HRV 2.2 software (University of Eastern Finland, Kuopio, Finland), which calculates measurements in the time-domain, frequency-domain and nonlinear dynamics of heart rate variability (HRV). ${ }^{27}$

We used three time-domain measures of HRV, which are derived from direct measurements of RR intervals: $i)$ the SD of all normal-to-normal RR intervals in the entire recording (SDNN); ii) the square root of the mean of the sum of squares of difference between adjacent RR intervals (RMSSD); and iii) the percentage of differences between adjacent RR intervals that are greater than $50 \mathrm{~ms}$ (pNN50).

We used an autoregressive model to estimate the power spectrum densities for the frequency-domain indexes of HRV from a data set length of 256 beats. The power spectra were quantified by measuring the area in three frequency bands: i) very low frequency (VLF, 0 to $0.04 \mathrm{~Hz}$ ); ii) low frequency power (LF, 0.04 to $0.15 \mathrm{~Hz}$ ); and iii) high frequency power $(\mathrm{HF}, 0.15$ to $0.40 \mathrm{~Hz})$. Additionally, the LF and HF oscillatory components are presented in normalized units (\%) and LF/HF ratio was calculated. The normalized unit expresses the power centered in the frequency of interest divided by total power minus very low frequency power. ${ }^{27}$

In addition to time-domain and frequency-domain measures of HRV, four nonlinear dynamics methods were used: i) Poincaré plot (SD1 and SD2); ii) approximate entropy; iii) sample entropy; and iv) correlation dimension (D2). ${ }^{27}$

\section{Laboratory tests}

All subjects received the same food at dinner the night before the assessment, and measurements were taken after rest and controlled fasting for 12 hours. Cobas ${ }^{\circledR}$ (Roche Diagnostics, EEUU), which uses the absorbance method, was used to quantify fasting glucose, total cholesterol, high-density lipoprotein cholesterol, low-density lipoprotein cholesterol, and triglycerides. Chemiluminescence was used for blood insulin. The HOMA insulin resistance index was calculated from fasting glucose and insulin levels. ${ }^{28}$ Total cardiovascular disease risk was calculated with the Framingham equation. ${ }^{29}$ To quantify physical activity, the Global Physical Activity Questionnaire was used. ${ }^{30}$

\section{Statistical analysis}

A necessary sample size of 60 subjects (30 in each group) was calculated, taking into account a mean difference in SVR between the two groups of $650 \mathrm{dyn} \cdot \mathrm{s} \cdot / \mathrm{cm}^{5}$, a standard deviation of 840 dyn.s $/ \mathrm{cm}^{5}$, a $95 \%$ confidence, a power of $80 \%$, and a potential loss of $10 \%$.

The Shapiro-Wilk test was used to evaluate whether the variables came from a normally distributed population. For the description of quantitative variables, the average, standard deviation, median, and interquartile range were used. For a description of the nominal variables, proportions were used. Quantitative variables were compared between the groups before the intervention with Student's $t$-test or the Mann-Whitney U-test, depending on whether they came from a normally distributed population. Qualitative variables were compared with the $\chi^{2}$ test. Intra-group differences before and after the intervention were obtained by the paired Student's $t$-test or Wilcoxon test. To establish the differences between groups after the intervention, the linear model with baseline correction was used (analysis of covariance; ANCOVA). ${ }^{31}$ For all analyses, a statistical significance level of $\alpha=0.05$ was used, and the IBM SPSS Statistics software, version 21.0, was employed.

Informed consent was obtained from all individual participants included in the study; standards for health research from the Ministry of Social Protection of Colombia in Resolution 008430 of 1993 and the principles of the Declaration of Helsinki were taken into account. ${ }^{32}$ The Ethics Committee of Indeportes-Antioquia approved the research protocol.

\section{Results}

159 medical records that belonged to potential candidate subjects were selected initially to participate in the study for presenting multiple cardiovascular risk factors. In an initial screening, 96 people were evaluated; of these, 67 met the inclusion criteria, but only 60 agreed to participate. During the stress test at baseline, one female patient presented angina and required referral to rule out coronary disease. From a total of 59 individuals ( 10 men and 49 women), 30 were randomly assigned to the intervention group and 29 to the control group. At follow-up, 2 subjects in the control group were excluded. Ultimately, 30 subjects in the intervention group and 27 subjects of the control group were included in the analysis (Fig. 1). 


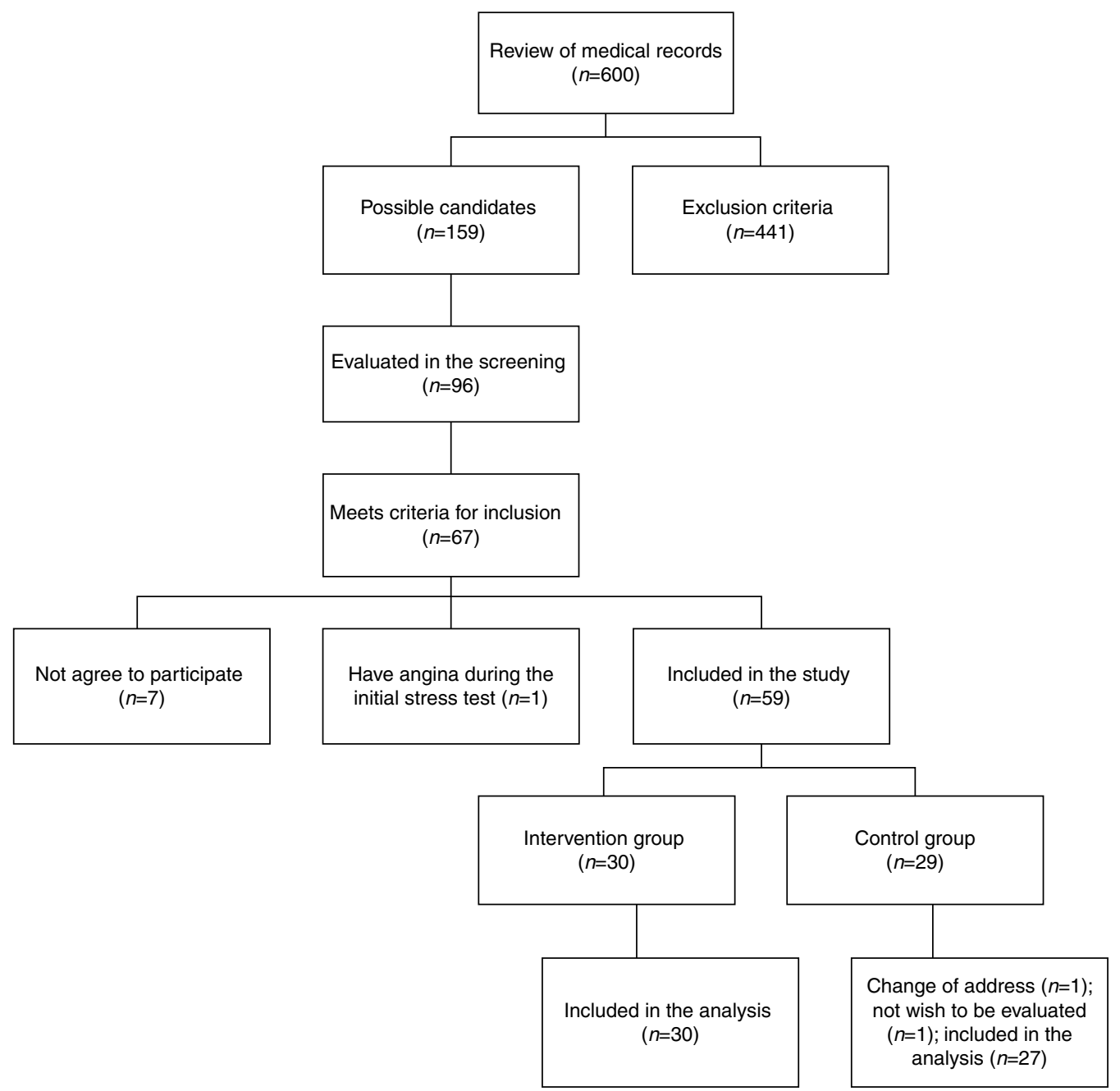

Figure 1 Flowchart showing the process of inclusion of the patients participating in the study.

When baseline socio-demographic, clinical, and anthropometric characteristics, as well as those related to lifestyle, laboratory measurements, and physical abilities, were compared between the individuals assigned to the intervention group and those included in the control group, no differences were found $(p>0.05)$ (Table 1$)$.

In the intervention group, there was an average compliance percentage of attendance to exercise and nutrition education sessions of $89.2 \%$ and $88.4 \%$, respectively. After the intervention, the group performing the exercise program and attending nutrition education activities obtained an increase in treadmill time to exhaustion during exercise test $(0.53 \mathrm{~min}, 95 \% \mathrm{Cl}, 0.05$ to $1.01 ; \mathrm{p}<0.05)$ and $\mathrm{VO}_{2} \max$ $\left(1.7 \mathrm{~mL} \mathrm{O} \cdot \mathrm{kg}^{-1} \cdot \min ^{-1} ; 95 \% \mathrm{Cl}, 0.1\right.$ to $\left.3.3 ; \mathrm{p}<0.05\right)$ and strength in elbow flexors $(11.8$ lbs; $95 \% \mathrm{Cl}, 9.4$ to 14.2 ; $\mathrm{p}<0.001$ ) and knee extensors (16.5 lbs; $95 \% \mathrm{Cl}, 12.9$ to 20.0 ; $p<0.001)$, and they performed a greater number of repetitions in the abdominal test $(7.8$ repetitions, $95 \% \mathrm{Cl}, 4.8$ to $10.8 ; \mathrm{p}<0.001)$ and sit-ups (5.6 repetitions, $95 \% \mathrm{Cl}, 3.1$ to $8.1 ; \mathrm{p}<0.001)$. Additionally, at the end of the study, the intervention group decreased body weight $(-2.8 \mathrm{~kg} ; 95 \% \mathrm{Cl}$, -3.8 to $-1.8 ; \mathrm{p}<0.001)$, body mass index $\left(-1.2 \mathrm{~kg} / \mathrm{m}^{2} ; 95 \%\right.$ $\mathrm{Cl},-1.6$ to $-0.7 ; \mathrm{p}<0.001)$, waist circumference $(-5.2 \mathrm{~cm}$;
$95 \% \mathrm{Cl},-6.9$ to $-3.5 ; \mathrm{p}<0.001)$, body fat percentage $(-2.1 \%$; $95 \% \mathrm{Cl},-2.8$ to $-1.4 ; \mathrm{p}<0.001)$, and the 10 -year total cardiovascular risk score $(-1.5 \% ; 95 \% \mathrm{Cl},-2.7$ to $-0.3 ; \mathrm{p}<0.05)$. The control group showed no changes in the variables described above (data not shown).

\section{Hemodynamic assessment}

When comparing the before and the after in the sitting position in the intervention group, a decrease in systolic blood pressure of $-9.6 \mathrm{mmHg}(95 \% \mathrm{Cl},-14.32$ to $-4.87 ; \mathrm{p}<0.001)$ was found, as well as a diastolic blood pressure of $-5.9 \mathrm{mmHg}$ $(95 \% \mathrm{Cl},-9.79$ to $-1.93 ; \mathrm{p}=0.005)$, a mean arterial pressure of $-7.8 \mathrm{mmHg}(95 \% \mathrm{Cl},-12.84$ to $-2.75 ; \mathrm{p}=0.004)$ (Fig. 2a), and a SVR index of -864.29 dyn.s. $\mathrm{m}^{2} / \mathrm{cm}^{5}(95 \% \mathrm{Cl},-1506.31$ to -222.26; $p=0.010$ ) (Fig. 2c). Increases were also observed in the stroke volume index of $7.26 \mathrm{~mL} / \mathrm{m}^{2}(95 \% \mathrm{Cl}, 2.32$ to $12.20 ; \mathrm{p}=0.005)$, cardiac output index of $0.48 \mathrm{~L} / \mathrm{min} / \mathrm{m}^{2}$ ( $95 \% \mathrm{Cl}, 0.14$ to $0.83 ; \mathrm{p}=0.007$ ) (Fig. $2 \mathrm{~b}$ ), speed index of $0.0081 / \mathrm{s}(95 \% \mathrm{Cl}, 0.003$ to $0.011 ; \mathrm{p}<0.001)$ (Fig. $2 \mathrm{~d}$ ), and acceleration index of $0.131 / \mathrm{s}^{2}(95 \% \mathrm{Cl}, 0.07$ to 0.18 ; $\mathrm{p}<0.001$ ) (Fig. 2e). When comparing the before and the 
Table 1 Patient characteristics.

\begin{tabular}{|c|c|c|}
\hline Variables & Intervention $(n=30)$ & Control $(n=29)$ \\
\hline \multicolumn{3}{|l|}{ Socio-demographic } \\
\hline Age (years) & $49.2 \pm 8.7$ & $52.0 \pm 6.8$ \\
\hline Female & $86.7 \%$ & $82.8 \%$ \\
\hline \multicolumn{3}{|l|}{ Body composition } \\
\hline Body mass index $\left(\mathrm{kg} \cdot \mathrm{m}^{2}\right)$ & $29.0 \pm 3.0$ & $28.3 \pm 4.0$ \\
\hline Body fat $(\%)$ & $40.0 \pm 5.6$ & $38.1 \pm 6.1$ \\
\hline \multicolumn{3}{|l|}{ Lifestyle } \\
\hline Smoking & $13.3 \%$ & $6.9 \%$ \\
\hline Alcohol consumption (last 12 month) & $40.0 \%$ & $34.5 \%$ \\
\hline Low physical activity & $46.7 \%$ & $58.6 \%$ \\
\hline \multicolumn{3}{|l|}{ Laboratory measurements } \\
\hline Total cholesterol (mg/dL) & $203.0 \pm 29.9$ & $217.6 \pm 33.4$ \\
\hline Low-density lipoprotein cholesterol (mg/dL) & $136.0 \pm 29.0$ & $148.7 \pm 30.8$ \\
\hline Triglycerides $(\mathrm{mg} / \mathrm{dL})$ & $174.1 \pm 70.5$ & $179.1 \pm 77.7$ \\
\hline High-density lipoprotein cholesterol (mg/dL) & $47.9 \pm 10.4$ & $48.7 \pm 11.5$ \\
\hline Glucose $(\mathrm{mg} / \mathrm{dL})$ & $106.5 \pm 38.8$ & $100.5 \pm 37.0$ \\
\hline Insulin resistance & $3.7 \pm 1.9$ & $3.1 \pm 1.8$ \\
\hline Insulin sensitivity (HOMA, \%) & $35.5 \pm 20.3$ & $46.1 \pm 32.1$ \\
\hline$\beta$-Cell function (HOMA, \%) & $185.2 \pm 103.0$ & $161.1 \pm 75.4$ \\
\hline \multicolumn{3}{|l|}{ Physical abilities } \\
\hline Treadmill time to exhaustion (min) & $9.7 \pm 1.9$ & $9.1 \pm 2.1$ \\
\hline $\mathrm{VO}_{2} \max \left(\mathrm{mL} \mathrm{O}_{2} \cdot \mathrm{Kg}^{-1} \cdot \mathrm{min}^{-1}\right)$ & $37.9 \pm 6.4$ & $36.1 \pm 7.0$ \\
\hline \multicolumn{3}{|l|}{ Medications } \\
\hline Angiotensin-converting enzyme inhibitors & $60.0 \%$ & $69.0 \%$ \\
\hline Angiotensin II receptor blockers & $26.7 \%$ & $10.3 \%$ \\
\hline$\beta$-Blockers & $26.7 \%$ & $10.3 \%$ \\
\hline Calcium antagonists & $20.0 \%$ & $20.7 \%$ \\
\hline Acetylsalicylic acid & $20.0 \%$ & $27.6 \%$ \\
\hline Statins & $43.3 \%$ & $44.8 \%$ \\
\hline Oral hypoglycemics & $16.7 \%$ & $6.9 \%$ \\
\hline Insulin & $3.3 \%$ & $6.9 \%$ \\
\hline 10-year total cardiovascular risk score & $8.7 \pm 7.2$ & $8.5 \pm 5.1$ \\
\hline
\end{tabular}

Data are presented as mean \pm SD when appropriate

HOMA: The homeostasis model assessment. $\mathrm{VO}_{2}$ max: Maximal oxygen consumption

after, the control group showed no changes in the sitting position. Comparisons of hemodynamic variables between the two groups at 12 weeks showed an increase in the speed index and acceleration index in the intervention group $(\mathrm{p}<0.05)$ (Table 2 and Fig. 2).

The results of the intragroup and intergroup comparisons in the standing position showed similar findings in hemodynamic variables to those reported in the sitting position (Fig. 3).

\section{Autonomic evaluation}

When comparing the before and the after, the intervention group showed a decrease in the sitting-position LF/HF ratio of $-0.52(95 \% \mathrm{Cl},-1.02$ to $-0.02 ; p=0.040)$ (Fig. $2 f)$. There were no differences in the other variables analyzed. When comparing the before and the after, the control group showed no changes in sitting-position variables. Comparisons of the autonomic variables between the two groups at 12 weeks showed a decrease of the LF/HF ratio in the intervention group $(\mathrm{p}<0.05)$ (Table 3 and Fig. 2 ).

The results of the intragroup and intergroup comparisons in the standing position showed similar findings in the autonomic variables to those reported in the sitting position (Fig. 3).

\section{Discussion}

The main finding of our study was that an intervention of dancing and nutrition education conducted for 12 weeks reduced blood pressure (systolic and diastolic) and SVR; it also increased the cardiac output and indicators of left ventricular systolic function (speed index and acceleration index), and improved sympathovagal balance in patients with MS.

Different studies conducted in patients with MS undergoing exercise and nutrition interventions have also shown decreases in systolic and diastolic arterial blood pressure similar to our results. ${ }^{33,34}$ However, the effect is greater 

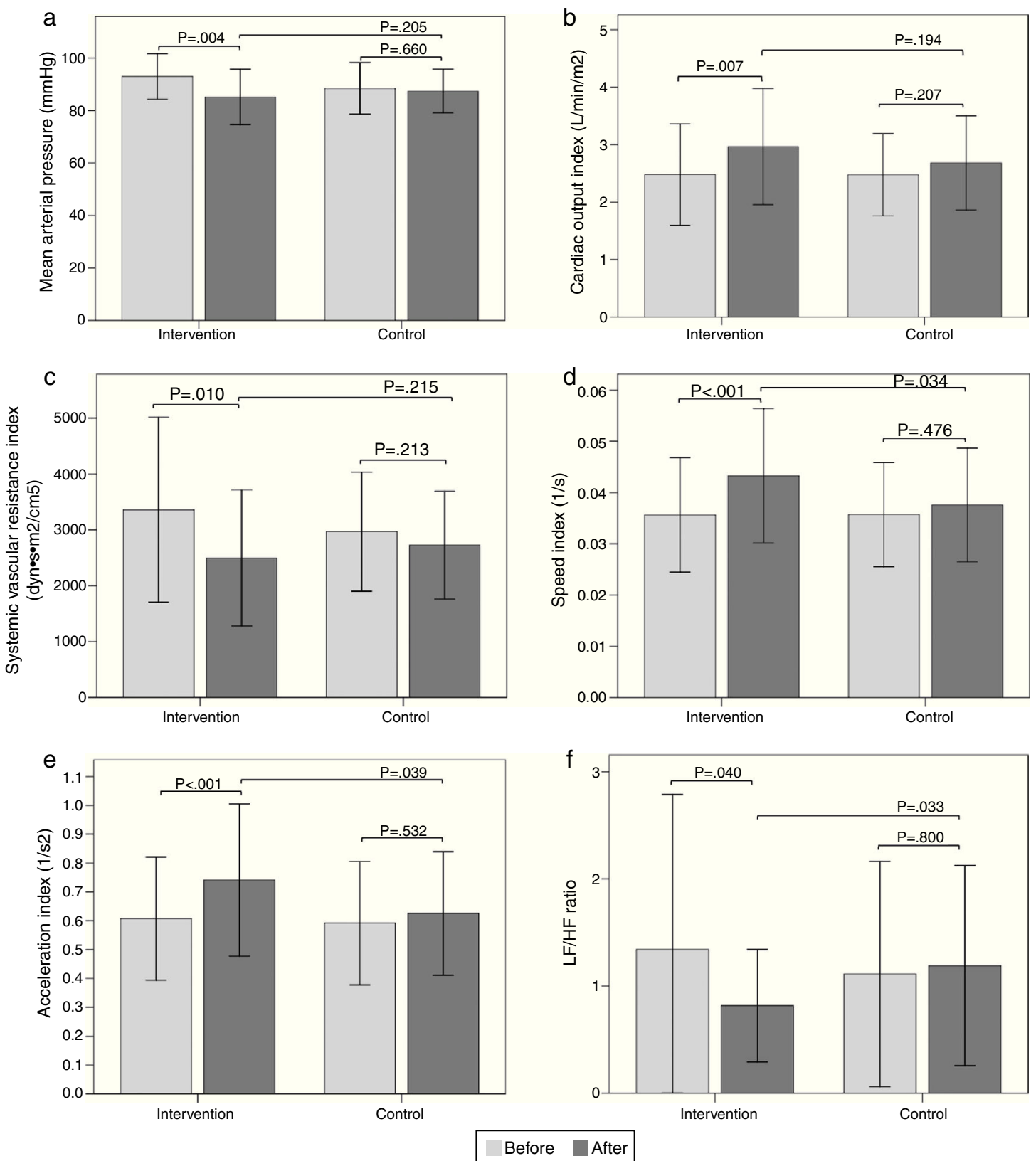

Figure 2 Figura 2 Bar graph showing comparison of hemodynamic and autonomic variables in the sitting position between the two groups before and after intervention. a) Mean arterial pressure; b) Cardiac output index; c) Systemic vascular resistance index; d) Speed index; e) Acceleration index; f) LF/HF ratio. Values are means \pm SD.

when both strategies are simultaneously combined. ${ }^{34}$ These results as well as ours suggest the need to include changes in diet and exercise as part of treatment for patients with MS, to produce a greater effect on arterial blood pressure.

Regular aerobic exercise at moderate intensity reduces arterial systolic blood pressure between $6-10 \mathrm{mmHg}$ and arterial diastolic blood pressure between $4-8 \mathrm{mmHg}$ in patients with essential hypertension. ${ }^{35-37}$ Additionally, a restriction of sodium intake to $2,300 \mathrm{mg}$ per day, increasing the intake of vegetables, fruit, and fiber, and lowering saturated fats in the diet can lower systolic blood pressure between $2-14 \mathrm{mmHg} .{ }^{38}$ It has been estimated that a reduction of $5 \mathrm{mmHg}$ in systolic blood pressure in the population produces a decrease of $14 \%$ in stroke mortality, $9 \%$ in coronary heart disease mortality, and $7 \%$ in all-cause mortality. ${ }^{38}$

Since blood pressure is determined by cardiac output and SVR, a reduction in blood pressure after an exercise and nutrition education intervention could be mediated by a decrease in one or both variables. Our findings show that the main mechanism explaining the reduction in resting arterial blood pressure after aerobic exercise training was a decrease in SVR. A Finnish cohort study that followed 1,741 young adults for 6 years and assessed the relationship between MS and different hemodynamic variables (measured with impedance cardiography) also reported a greater 
Table 2 Comparison of hemodynamic variables in the sitting position between the two groups before and after intervention.

\begin{tabular}{|c|c|c|c|c|c|c|c|c|c|c|c|}
\hline \multirow{3}{*}{$\begin{array}{l}\text { Hemodynamic } \\
\text { variables }\end{array}$} & \multicolumn{5}{|c|}{ Intervention $(n=30)$} & \multicolumn{5}{|c|}{ Control $(n=27)$} & \multirow[t]{3}{*}{$p$ value ${ }^{c}$} \\
\hline & \multicolumn{2}{|c|}{ Before } & \multicolumn{2}{|c|}{ After } & \multirow[t]{2}{*}{$p$ value ${ }^{a}$} & \multicolumn{2}{|c|}{ Before } & \multicolumn{2}{|c|}{ After } & \multirow[t]{2}{*}{$p$ value ${ }^{b}$} & \\
\hline & Mean & $\pm \mathrm{SD}$ & Mean & $\pm \mathrm{SD}$ & & Mean & $\pm \mathrm{SD}$ & Mean & $\pm \mathrm{SD}$ & & \\
\hline $\begin{array}{l}\text { Systolic blood } \\
\text { pressure } \\
(\mathrm{mmHg})\end{array}$ & 120.5 & 10.9 & 110.9 & 11.5 & $<0.001$ & 115.6 & 13.2 & 114.3 & 15.5 & 0.629 & 0.078 \\
\hline $\begin{array}{l}\text { Diastolic blood } \\
\text { pressure } \\
(\mathrm{mmHg})\end{array}$ & 79.0 & 9.4 & 73.1 & 9.5 & 0.005 & 75.2 & 8.1 & 74.6 & 5.8 & 0.698 & 0.174 \\
\hline $\begin{array}{l}\text { Mean blood } \\
\text { pressure } \\
(\mathrm{mmHg})\end{array}$ & 92.9 & 8.6 & 85.1 & 10.5 & 0.004 & 88.4 & 9.8 & 87.4 & 8.3 & 0.660 & 0.205 \\
\hline Heart rate (bpm) & 73.1 & 11.2 & 71.9 & 12.1 & 0.603 & 70.7 & 9.0 & 74.7 & 12.3 & 0.050 & 0.152 \\
\hline $\begin{array}{l}\text { Stroke volume } \\
\text { index }\left(\mathrm{mL} / \mathrm{m}^{2}\right)\end{array}$ & 35.4 & 12.6 & 42.7 & 16.5 & 0.005 & 35.7 & 11.1 & 36.6 & 12.7 & 0.697 & 0.072 \\
\hline $\begin{array}{l}\text { Cardiac output } \\
\text { index } \\
\left(\mathrm{L} / \mathrm{min} / \mathrm{m}^{2}\right)\end{array}$ & 2.5 & 0.9 & 3.0 & 1.0 & 0.007 & 2.5 & 0.7 & 2.7 & 0.8 & 0.207 & 0.194 \\
\hline $\begin{array}{l}\text { Systemic } \\
\text { vascular } \\
\text { resistance } \\
\text { index } \\
\left(\text { dyn.s. } \mathrm{m}^{2} / \mathrm{cm}^{5}\right)\end{array}$ & 3360.4 & 1657.4 & 2496.1 & 1216.8 & 0.010 & 2967.4 & 1065.5 & 2725.2 & 964.6 & 0.213 & 0.215 \\
\hline $\begin{array}{l}\text { Pre-ejection } \\
\quad \text { period (s) }\end{array}$ & 0.135 & 0.152 & 0.109 & 0.031 & 0.365 & 0.098 & 0.032 & 0.095 & 0.024 & 0.593 & 0.109 \\
\hline $\begin{array}{l}\text { Left ventricular } \\
\text { ejection time } \\
\text { (s) }\end{array}$ & 0.328 & 0.046 & 0.331 & 0.051 & 0.790 & 0.346 & 0.038 & 0.342 & 0.034 & 0.698 & 0.570 \\
\hline $\begin{array}{l}\text { Systolic time } \\
\text { ratio }\end{array}$ & 0.5 & 0.7 & 0.3 & 0.1 & 0.367 & 0.3 & 0.1 & 0.3 & 0.1 & 0.934 & 0.061 \\
\hline $\begin{array}{l}\text { Speed index } \\
(1 / \mathrm{s})\end{array}$ & 0.036 & 0.011 & 0.043 & 0.013 & $<0.001$ & 0.036 & 0.010 & 0.038 & 0.011 & 0.476 & 0.034 \\
\hline $\begin{array}{l}\text { Acceleration } \\
\text { index }\left(1 / \mathrm{s}^{2}\right)\end{array}$ & 0.6 & 0.2 & 0.7 & 0.3 & $<0.001$ & 0.6 & 0.2 & 0.6 & 0.2 & 0.532 & 0.039 \\
\hline $\begin{array}{l}\text { Left ventricular } \\
\text { work index } \\
\left(\mathrm{kg} \cdot \mathrm{m} / \mathrm{min} . \mathrm{m}^{2}\right)\end{array}$ & 2.9 & 1.0 & 3.2 & 1.1 & 0.230 & 2.8 & 0.9 & 3.0 & 1.0 & 0.327 & 0.608 \\
\hline
\end{tabular}

decreased SVR in those subjects who recovered from MS with changes in lifestyle. ${ }^{4}$

After an intervention with exercise and nutrition education, SVR reduction could be mediated by neuro-hormonal 33,35 adaptations in the vascular structure $^{35,39}$ or function. ${ }^{10,35}$ Regarding the potential neuro-hormonal adaptations that may explain the reduction of SVR and blood pressure as a result of exercise training, a decrease in central sympathetic activity, norepinephrine release, and plasma renin activity has been described, as well as an increase in baroreflex sensitivity and an inhibition of renal sympathetic outflow. ${ }^{33,35,40}$ Regarding changes in vascular structure, there is evidence that exercise can produce remodeling (increase in length, cross-sectional area, and diameter) and angiogenesis in muscle vessels. ${ }^{35}$ However, the major finding explaining the decrease in blood pressure and SVR is the reduction in precapillary vascular resistance, possibly due to the increased number of muscle precapillary vessels, which increases the cross-sectional area of resistance vessels. ${ }^{39}$ The changes in vascular function that result from exercise training include a lower response of $\alpha$-adrenergic receptors to norepinephrine stimulation, ${ }^{41}$ a decrease in endothelin-1 levels, ${ }^{42}$ and an increase in the production of nitric oxide, ${ }^{10}$ which contributes to a reduction in vascular tone and SVR.

After the intervention of dancing and nutrition education, we found increased indicators of systolic function such as the speed index, acceleration index, stroke volume, and cardiac output. We cannot exclude that these findings may be explained by an adaptation of the myocardium 

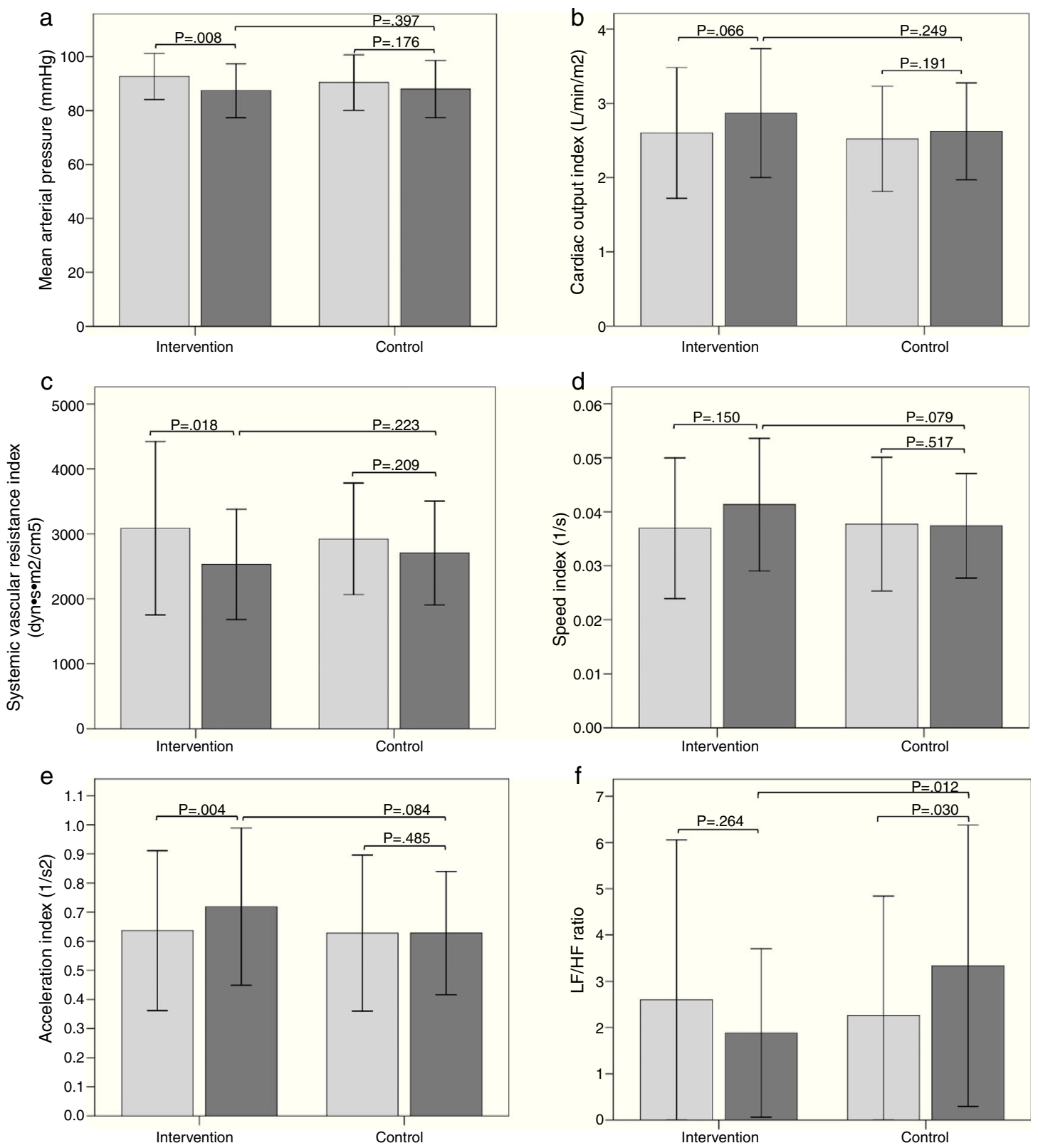

Before After

Figure 3 Bar graph showing comparison of hemodynamic and autonomic variables in the standing position between the two groups before and after intervention. a) Mean arterial pressure; b) Cardiac output index; c) Systemic vascular resistance index; d) Speed index; e) Acceleration index; f) LF/HF ratio. Values are means \pm SD.

to the intervention applied, but these most likely may be secondary to decreased SVR leading to a reduction in afterload.

Patients with MS have a decreased HRV, ${ }^{43}$ which is explained by the state of hyperinsulinemia, increased noradrenaline secretion in sympathetic nerves, and impairment of arterial baroreflex function. ${ }^{6}$ A reduction in HRV increases the risk of mortality from cardiovascular disease. ${ }^{44}$ However, regular exercise induces various changes in the ANS that can counteract the neuro-endocrine disorders presented by patients with MS. ${ }^{11}$ Regular aerobic training decreases resting heart rate and increases HRV due to increased baroreflex sensitivity, greater efferent parasympathetic activity, and reduced efferent sympathetic activity. ${ }^{11}$

A controlled clinical trial evaluating the effect of an aerobic exercise program of moderate intensity at $70-80 \%$ of maximum heart rate, at high or moderate volume, for 8 weeks in sedentary people reported favorable changes in cardiac autonomic regulation in both groups, characterized by an increase in the HF component and a decrease in the LF component and the LF/HF ratio of the HRV spectral analysis, after the exercise training program. ${ }^{45}$ The results of that study are consistent with our findings, which indicated a decrease in the LF/HF ratio of HRV in the intervention 
Table 3 Comparison of autonomic variables in the sitting position between the two groups before and after intervention.

\begin{tabular}{|c|c|c|c|c|c|c|c|c|c|c|c|}
\hline \multirow{3}{*}{$\begin{array}{l}\text { Autonomic } \\
\text { variables }\end{array}$} & \multicolumn{5}{|c|}{ Intervention $(n=30)$} & \multicolumn{5}{|c|}{ Control $(n=27)$} & \multirow[t]{3}{*}{$p$ value } \\
\hline & \multicolumn{2}{|l|}{ Before } & \multicolumn{2}{|l|}{ After } & \multirow[t]{2}{*}{$p$ value ${ }^{a}$} & \multicolumn{2}{|c|}{ Before } & \multicolumn{2}{|l|}{ After } & \multirow[t]{2}{*}{$\mathrm{p}$ value ${ }^{\mathrm{b}}$} & \\
\hline & Mean & $\pm \mathrm{SD}$ & Mean & $\pm \mathrm{SD}$ & & Mean & $\pm \mathrm{SD}$ & Mean & $\pm \mathrm{SD}$ & & \\
\hline \multicolumn{12}{|l|}{ Time - domain } \\
\hline SDNN (ms) & 44.5 & 22.6 & 44.8 & 24.7 & 0.970 & 39.2 & 23.1 & 34.3 & 20.4 & 0.190 & 0.141 \\
\hline RMSSD (ms) & 42.7 & 34.4 & 41.7 & 35.0 & 0.890 & 39.1 & 35.8 & 32.1 & 26.1 & 0.160 & 0.265 \\
\hline pNN50 (\%) & 12.9 & 15.6 & 18.0 & 19.9 & 0.160 & 12.0 & 16.1 & 10.3 & 15.0 & 0.380 & 0.071 \\
\hline \multicolumn{12}{|l|}{ Frequency-domain } \\
\hline LF (\%) & 44.8 & 22.8 & 40.7 & 15.4 & 0.320 & 43.7 & 20.8 & 48.0 & 17.1 & 0.280 & 0.059 \\
\hline HF (\%) & 55.0 & 22.7 & 59.1 & 15.4 & 0.310 & 56.1 & 20.7 & 51.9 & 17.1 & 0.280 & 0.059 \\
\hline LF/HF ratio & 1.3 & 1.4 & 0.8 & 0.5 & 0.040 & 1.1 & 1.1 & 1.2 & 0.9 & 0.800 & 0.033 \\
\hline \multicolumn{12}{|l|}{ Poincare plot } \\
\hline SD1 (ms) & 30.3 & 24.4 & 29.6 & 24.8 & 0.890 & 27.7 & 25.3 & 22.7 & 18.5 & 0.160 & 0.266 \\
\hline SD2 (ms) & 53.5 & 25.2 & 54.8 & 27.0 & 0.850 & 46.5 & 24.1 & 42.3 & 23.3 & 0.340 & 0.114 \\
\hline \multicolumn{12}{|l|}{ Other nonlinear results } \\
\hline Approximate entropy & 1.0 & 0.2 & 1.0 & 0.1 & 0.440 & 1.0 & 0.1 & 1.1 & 0.1 & 0.550 & 0.265 \\
\hline Sample entropy & 1.4 & 0.4 & 1.4 & 0.3 & 0.600 & 1.6 & 0.3 & 1.6 & 0.2 & 0.990 & 0.231 \\
\hline Correlation dimension & 2.0 & 1.5 & 2.1 & 1.7 & 0.550 & 1.5 & 1.3 & 1.4 & 1.5 & 0.830 & 0.302 \\
\hline
\end{tabular}

group, and may explain the decrease in SVR and arterial blood pressure due to an improvement in sympathovagal balance.

Alterations of heart rate regularity in patients with MS measured by nonlinear dynamic methods such as approximate entropy, ${ }^{46}$ have been described. Entropy is a tool for the analysis of nonlinear signals, which provides an independent model to measure the irregularity and complexity of different over-time series. In individuals with MS, greater heart rate irregularity has been reported, and entropy increases with the number of MS components. ${ }^{46}$ In this study, a relationship between entropy and the impedance of the aorta as determined by volumetric expansion was found, demonstrating that MS causes an imbalance in sympathetic tone and alters the intra-thoracic mechanical capacity of the cardiovascular system. ${ }^{46}$ Although some studies have shown the effect of aerobic exercise on measurements of nonlinear dynamics, such as an increase in the standard deviation in the Poincaré plot, ${ }^{45,47}$ we observed no changes as a result of the evaluated intervention, either for the entropy or for other measurements of nonlinear dynamics.

To our knowledge, few reports have evaluated the combined effect of an intervention with exercise and nutrition education on hemodynamic and autonomic variables in patients with MS in a rural area. ${ }^{34}$ However, the results obtained in this study are consistent with the cardiovascular changes resulting from exercise training that have been observed in healthy individuals with risk factors and in those with cardiovascular disease. ${ }^{10,35}$ One of the main strengths of this study was the high adherence to the intervention unlike those reported in other studies, ${ }^{48}$ which can be explained by the implementation of a strategy in group and the inclusion of dancing as a form of aerobic exercise training.

The limitations of the study include the inability to blind the intervention to participants. Also, due to the site where they lived (rural area) and the close relationship between the subjects involved in this research, it is possible that some contamination might have existed. Even though this latter limitation could be contrary to the study hypothesis, despite this, some important hemodynamic and autonomic changes were found in the intervention group.

In our study, the group of patients with MS who received the intervention of dancing and nutrition education showed decreases in body weight, body mass index, waist circumference, and body fat percentage. However, our design did not allow us to estimate the extent to which the decrease in arterial blood pressure and SVR was explained by changes in body composition or by the intervention applied. Finally, we made no adjustments for multiple comparisons which introduce an increased chance of a type I error. However, the consistency of our findings with our prespecified hypotheses makes unlikely that our conclusions were reached by chance alone.

\section{Conclusions}

An intervention with dancing and nutrition education lowers arterial blood pressure and SVR, increases indicators of systolic function and has favorable effects on the sympathovagal balance in patients with MS. 


\section{Ethical disclosures}

Protection of human and animal subjects. The authors declare that the procedures followed were in accordance with the regulations of the relevant clinical research ethics committee and with those of the Code of Ethics of the World Medical Association (Declaration of Helsinki).

Confidentiality of data. The authors declare that they have followed the protocols of their work center on the publication of patient data.

Right to privacy and informed consent. The authors have obtained the written informed consent of the patients or subjects mentioned in the article. The corresponding author is in possession of this document.

\section{Funding}

This research was supported with funds from the program "For Your Health, Move" of Indeportes-Antioquia and the SICOR Clinical and Research Center.

\section{Conflict of interest}

The authors declare no conflict of interest.

\section{Acknowledgments}

The authors thank all those who agreed to participate, the San Juan de Dios Local Hospital of Valparaiso Antioquia, the staff from Indeportes-Antioquia, and the SICOR Clinical and Research Center. DPC was a research trainee in the hypertension and cardiovascular risk line, partially supported by Colciencias under the contact 436-2009.

\section{References}

1. Cameron AJ, Shaw JE, Zimmet PZ. The metabolic syndrome: prevalence in worldwide populations. Endocrinol Metab Clin North Am. 2004;33:351-75.

2. Alberti KG, Eckel RH, Grundy SM, Zimmet PZ, Cleeman JI, Donato KA, et al. Harmonizing the metabolic syndrome: a joint interim statement of the International Diabetes Federation Task Force on Epidemiology and Prevention; National Heart, Lung, and Blood Institute; American Heart Association; World Heart Federation; International Atherosclerosis Society; and International Association for the Study of Obesity. Circulation. 2009;120:1640-5.

3. Eckel RH, Grundy SM, Zimmet PZ. The metabolic syndrome. Lancet. 2005;365:1415-28.

4. Koivistoinen $\mathrm{T}$, Aatola $\mathrm{H}$, Hutri-Kahonen N, Juonala M, Viikari JS, Laitinen T, et al. Systemic hemodynamics in young adults with the metabolic syndrome: the Cardiovascular Risk in Young Finns Study. Ann Med. 2010;42:612-21.

5. Baron AD. Hemodynamic actions of insulin. Am J Physiol. 1994;267 2 Pt 1:E187-202.

6. Mancia G, Bousquet P, Elghozi JL, Esler M, Grassi G, Julius S, et al. The sympathetic nervous system and the metabolic syndrome. J Hypertens. 2007;25:909-20.

7. Muniyappa R, Montagnani M, Koh KK, Quon MJ. Cardiovascular actions of insulin. Endocr Rev. 2007;28:463-91.
8. Kokkinos P, Myers J. Exercise and physical activity: clinical outcomes and applications. Circulation. 2010;122:1637-48.

9. Grassi G, Seravalle G, Calhoun DA, Mancia G. Physical training and baroreceptor control of sympathetic nerve activity in humans. Hypertension. 1994;23:294-301.

10. Kojda G, Hambrecht R. Molecular mechanisms of vascular adaptations to exercise. Physical activity as an effective antioxidant therapy? Cardiovasc Res. 2005;67:187-97.

11. Carter JB, Banister EW, Blaber AP. Effect of endurance exercise on autonomic control of heart rate. Sports Med. 2003;33:33-46.

12. Toft UN, Kristoffersen LH, Aadahl M, von Huth Smith L, Pisinger C, Jorgensen T. Diet and exercise intervention in a general population-mediators of participation and adherence: the Inter99 study. Eur J Public Health. 2007;17:455-63.

13. Chen $M$, He M, Min X, Pan A, Zhang X, Yao P, et al. Different physical activity subtypes and risk of metabolic syndrome in middle-aged and older Chinese people. Plos One. 2013;8:e53258.

14. Belardinelli R, Lacalaprice F, Ventrella C, Volpe L, Faccenda E. Waltz dancing in patients with chronic heart failure: new form of exercise training. Circ Heart Fail. 2008;1:107-14.

15. Keogh JW, Kilding A, Pidgeon P, Ashley L, Gillis D. Physical benefits of dancing for healthy older adults: a review. J Aging Phys Act. 2009;17:479-500.

16. Orchard TJ, Temprosa M, Goldberg R, Haffner S, Ratner R, Marcovina S, et al. The effect of metformin and intensive lifestyle intervention on the metabolic syndrome: the Diabetes Prevention Program randomized trial. Ann Intern Med. 2005;142:611-9.

17. Straznicky NE, Lambert EA, Lambert GW, Masuo K, Esler MD, Nestel PJ. Effects of dietary weight loss on sympathetic activity and cardiac risk factors associated with the metabolic syndrome. J Clin Endocrinol Metab. 2005;90:5998-6005.

18. Prochaska JO, Velicer WF. The transtheoretical model of health behavior change. Am J Health Promot. 1997;12:38-48.

19. Smitasiri S, Dhanamitta S. Nutri-action analysis as a research strategy to improve nutrition information, education and communication interventions in Asia. Biomed Environ Sci. 1996;9:290-5.

20. Pérez-Idarraga A, Valencia Gómez K, Gallo Villegas J, Arenas Sosa M, Quintero Velásquez MA. Intervention with rumba and nutrition education to modify cardiovascular risk factors in adults with metabolic syndrome. Rev Panam Salud Pública. 2015;37:29-37.

21. Bruce RA, Kusumi F, Hosmer D. Maximal oxygen intake and nomographic assessment of functional aerobic impairment in cardiovascular disease. Am Heart J. 1973;85:546-62.

22. Mancia G, De Backer G, Dominiczak A, Cifkova R, Fagard R, Germano G, et al. 2007 Guidelines for the Management of Arterial Hypertension: The Task Force for the Management of Arterial Hypertension of the European Society of Hypertension (ESH) and of the European Society of Cardiology (ESC). Journal of hypertension. 2007;25:1105-87.

23. Heyward $\mathrm{VH}$. Advanced fitness assessment and exercise prescription. 6th ed. Champaign, IL: Human Kinetics; 2010.

24. Lohman TG, Roche AF, Martorell R. Anthropometric standardization reference manual. Champaign, IL: Human Kinetics; 1988.

25. Durnin JV, Womersley J. Body fat assessed from total body density and its estimation from skinfold thickness: measurements on 481 men and women aged from 16 to 72 years. Br J Nutr. 1974;32:77-97.

26. Summers RL, Shoemaker WC, Peacock WF, Ander DS, Coleman TG. Bench to bedside: electrophysiologic and clinical principles of noninvasive hemodynamic monitoring using impedance cardiography. Acad Emerg Med. 2003;10:669-80.

27. Tarvainen MP, Niskanen JP, Lipponen JA, Ranta-Aho PO, Karjalainen PA. Kubios HRV-heart rate variability analysis software. Comput Methods Programs Biomed. 2014;113:210-20. 
28. Matthews DR, Hosker JP, Rudenski AS, Naylor BA, Treacher DF, Turner RC. Homeostasis model assessment: insulin resistance and beta-cell function from fasting plasma glucose and insulin concentrations in man. Diabetologia. 1985;28:412-9.

29. D’Agostino RB Sr, Vasan RS, Pencina MJ, Wolf PA, Cobain M, Massaro JM, et al. General cardiovascular risk profile for use in primary care: the Framingham Heart Study. Circulation. 2008; 117:743-53.

30. Bull FC, Maslin TS, Armstrong T. Global physical activity questionnaire (GPAQ): nine country reliability and validity study. J Phys Act Health. 2009;6:790-804.

31. Vickers AJ, Altman DG. Statistics notes: Analysing controlled trials with baseline and follow up measurements. BMJ. 2001;323:1123-4

32. Schuklenk U. Helsinki Declaration revisions. Issues Med Ethics. 2001;9:29.

33. Straznicky NE, Lambert EA, Nestel PJ, McGrane MT, Dawood T, Schlaich MP, et al. Sympathetic neural adaptation to hypocaloric diet with or without exercise training in obese metabolic syndrome subjects. Diabetes. 2010;59:71-9.

34. Christ M, Iannello C, Iannello PG, Grimm W. Effects of a weight reduction program with and without aerobic exercise in the metabolic syndrome. Int J Cardiol. 2004;97:115-22.

35. Pescatello LS, Franklin BA, Fagard R, Farquhar WB, Kelley GA, Ray CA. American College of Sports Medicine position stand. Exercise and hypertension. Med Sci Sports Exerc. 2004;36:533-53.

36. Wallace JP. Exercise in hypertension. A clinical review. Sports Med. 2003;33:585-98.

37. Fagard RH. Exercise characteristics and the blood pressure response to dynamic physical training. Med Sci Sports Exerc. 2001;33 6 Suppl:S484-92, discussion S493-484.

38. Chobanian AV, Bakris GL, Black HR, Cushman WC, Green LA, Izzo $J \mathrm{~L} J$ r, et al. The Seventh Report of the Joint National Committee on Prevention, Detection, Evaluation, and Treatment of High Blood Pressure: the JNC 7 report. JAMA. 2003;289:2560-72.
39. Sexton WL, Laughlin MH. Influence of endurance exercise training on distribution of vascular adaptations in rat skeletal muscle. Am J Physiol. 1994;266:H483-90.

40. Cornelissen VA, Fagard RH. Effects of endurance training on blood pressure, blood pressure-regulating mechanisms, and cardiovascular risk factors. Hypertension. 2005;46:667-75.

41. Wiegman DL, Harris PD, Joshua IG, Miller FN. Decreased vascular sensitivity to norepinephrine following exercise training. J Appl Physiol Respir Environ Exerc Physiol. 1981;51:282-7.

42. Maeda S, Miyauchi T, Kakiyama T, Sugawara J, lemitsu M, Irukayama-Tomobe $Y$, et al. Effects of exercise training of 8 weeks and detraining on plasma levels of endothelium-derived factors, endothelin-1 and nitric oxide, in healthy young humans. Life Sci. 2001;69:1005-16.

43. Stuckey MI, Tulppo MP, Kiviniemi AM, Petrella RJ. Heart rate variability and the metabolic syndrome: a systematic review of the literature. Diabetes Metab Res Rev. 2014;30:784-93.

44. Villareal RP, Liu BC, Massumi A. Heart rate variability and cardiovascular mortality. Curr Atheroscler Rep. 2002;4:120-7.

45. Tulppo MP, Hautala AJ, Makikallio TH, Laukkanen RT, Nissila $\mathrm{S}$, Hughson RL, et al. Effects of aerobic training on heart rate dynamics in sedentary subjects. J Appl Physiol (1985). 2003;95:364-72.

46. Guerra S, Boscari F, Avogaro A, Di Camillo B, Sparacino G, de Kreutzenberg SV. Hemodynamics assessed via approximate entropy analysis of impedance cardiography time series: effect of metabolic syndrome. Am J Physiol Heart Circ Physiol. 2011;301:H592-8.

47. Mourot L, Bouhaddi M, Perrey S, Rouillon JD, Regnard J. Quantitative Poincare plot analysis of heart rate variability: effect of endurance training. Eur J Appl Physiol. 2004;91:79-87.

48. Artinian NT, Fletcher GF, Mozaffarian D, Kris-Etherton P, Van Horn L, Lichtenstein AH, et al. Interventions to promote physical activity and dietary lifestyle changes for cardiovascular risk factor reduction in adults: a scientific statement from the American Heart Association. Circulation. 2010;122:406-41. 